tive anæmia while the amputation is being accomplished; and a loss of blood can be prevented, which, by deteriorating the general quality of the vital fluid, might have laid the foundation of subscquent discase. In fact, the value of a position by which the entrance of arterial blood into a linb will be retarded, and the exit of renous blood facilitated, is almost as useful in the performance of an operation as in the treatment of inflammation.-London Med. Times and Gazette.

\title{
CONTINUED HISTORY OF A CASE OF "GOUGING."
}

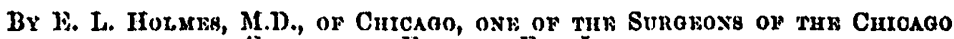

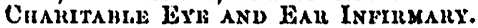

IN a former number of this Journal (December, 1859) may be found the history of a case of injury of the cyes which has scarcely a parallel in the annals of oplithalmic science. I have lately had an opportunity of examining the patient, and hope an account of his mesant condition will not be uninteresting to the readers of the Journal.

Fin the henefit of those who may hare forgotten the previous history of the casc, I may state that an Irishman, 37 years of agc, was attacked by some one, who forced his thumbs with such violence in to the patient's orbits as to rupture both globes. For six wecks the patient remained in the southern part of this State, totally blind, and received, as he stated, no other treatment than repeated doses of sulphate of magnesia, internally, and wet compresses locally. At the cxpiration of this time he was able to distinguish light, and gradually regained indistinct vision of large objects. Five months after the assault, the patient came under my care. With the right eyc he could see light and the shadows of objects passed in front of the eye; with the left eye he could, with a little assistance from an attendant, conduct himseif in any of the streets of Chicago. The cornea of each eye was perfectly nornal in appcarance. The upper and inner sixth of each iris was alssent; it had apparently been torn away, as in an operation for iridectomy. The pupils were consequently elongated. Ncar the inner extremity of each pupil was a cicatrix, at the union of the sclerotica and cornea, in which were involved particles of pigment, probably from the iris. A rupture of the globes had, without doubt, occurred at this place, and through the opening had evidently been forced the Inst portion of iris and crystalline lens of each eye, for in neither eye cusuld a trace of the lens be found. Trembling of the iris, usually observed after the removal of the lens, was absent in both eyes, probab!y on account of tension of the radiating fibres of the iris, produced by their contraction during cicatrization.

The vitreous humor of each eye was shown by the ophthalmo-

VoL. Lxix.-No. 5* 
scope to be so clouded with fine and black particles floating in its substance, that the vessels of the retina and the papilla of the optic nerve could [? not] be readily seen, especially in the right eyc:

By the use of a simple supporting treatinent the patient was so far improved in four months as to be able to walk without assist. ance and to read large signs across the street, although he conld not, even with the aid of double convex lenses, distinguish minute objects. The vitreous hunor of both eyes had become nearly transparent, although vision of the right eye had not improved.

A few weeks since, more than three years and a lialf after my former report, the pratient again consulted me in reference to his vision. Five months previously the perception of light in the right eye began to fail, and in less than four months it was wholly extinct. The vision of the other eye has remained as before, with possibly a slight improvenent. 'The only change noticcable by a simple inspection is a marked trembling of each iris, which, it will be remembered, was not present three years ago.

In the right eye neither papilla nor vessels can be discorered with the ophthalmoscope. Even the peculiar red disk, almost invariably observed through the pupil by the ophthalmoscope, cannot be seen.

By means of light concentrated by a powerful double convex lens obliquely upon the cornea, and thrown into the pupil, a dark-bluish mass can be secn lying bohind the iris; this is undonbtedly the retina, which has becu detached from the choroid.

The papilla of the oflier eye is of an oval form and of a greenishblue color. It apprear's smaller than in a normal eye. The line of demareation between the papilla and the retina is very distinet, exeept at its upper and outer portion, where a part of the optic nerve seems to be covered with lymph. Whether the oval form of the papilla is produced by an increase of convexity in the cornea in the direction corresponding to the long diancter of papilla, I am unable to say.

The ressels of the retina are fincr than in a normal condition of the eye, and appear more like solid threads than like vessels. The absence of the lous, which has a large magnilying power, will ac-count for the apparent decrease in the size of the papilla and vessels. 'The red appearance of the retina and choroid is somewhat darker than normal, and different portions of these membranes secm of" a different shade of redness._Chicago Mcelical Journal.

$\Lambda$ Vetranan Medical Jurist.-Casper, the renowned Professor of Legal Medicine at Berlin, a few weeks since celebrated a remarkable day in his lung and litburinus scinntilic: career, viz., the day on which he executed his thousandth medico-legal autopsy. He cortainly was justified in placing on the title-page of his "Manual of Legal Medicine," the epigraph "quod vidi scripsi." 